\title{
Biomass Based Bioenergy: Technologies and Impact on Environmental Sustainability
}

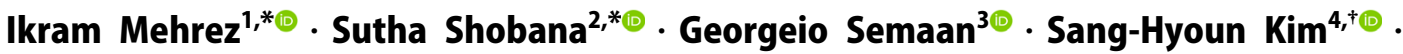 \\ Gopalakrishnan Kumar, ${ }^{3,4+\infty}$
}

'Laboratory of Energy, Environment and Information Systems, Faculty of Sciences and Technology, Adrar University, 01000 Adrar, Algeria

${ }^{2}$ Department of Chemistry \& Research Centre, Mohamed Sathak Engineering College, Kilakarai , Ramanathapuram District, Tamil Nadu - 623 806, India

${ }^{3}$ Institute of Chemistry, Bioscience and Environmental Engineering, Faculty of Science and Technology, University of Stavanger, Stavanger 4036, Norway

${ }^{4}$ School of Civil and Environmental Engineering, Yonsei University, Seoul, 03722, South Korea, Republic of Korea

(Received September 1, 2020; Revised December 2, 2021; Accepted December 2, 2021)

\begin{abstract}
Biomass based bioenergy has many advantages evidently as their available quantity and renewability, when compared to the petro-derived traditional fossil fuels. Thereby, such bioenergy occupies a vital role defensively to the global energy requirement as well as guarantee energy supply. On the other hand, it should be considered that the development of biomass based energy may lead to some serious environmental issues and those are only based on the published data. Such adverse environmental alterations, mainly erosion of soil organic carbon, greenhouse gas emissions, lessening of water quantity and quality, have mainly been based on type of biomass source utilized, location of the land, and management practices. Consequently, more attention should be paid towards environmental protection, while implementing the production of biomass based bioenergy. In this study, various types of biomass, its conversion technology, advantages and disadvantages and its environmental issues of bioenergy production in terms of adverse impact on water, air and soil along with protection measures have been discussed.
\end{abstract}

Keywords: Biomass based bioenergy, Types of biomass sources, Adverse environmental impact, Environmental protection

\footnotetext{
Corresponding author

E-mail: Gopalakrishnan.kumar@uis.no

Tel: +47-41320821

${ }^{\dagger+}$ Corresponding author

E-mail: sanghkim@yonsei.ac.kr

Tel: +82-2-2123-2802 Fax: +82-2-364-5300

* Authors have equal contribution to this work.

(C) 2022, Korean Society of Environmental Engineers
} 


\section{Introduction}

By the year 2030, the usage of various biomass resources would raise due to the increased demand of energy. The demand is would be possibly met by increased utilization of the waste biomass residues like starch, sugar, and oil crops, progressively more from lignocellulosic crops, which is based on the picking of crop and planting rates, environmental and logistical constraints, and availability of water resources. ${ }^{1)}$ The demand or necessities of global energy level increases hurriedly, due to rapid growth and developmental activities of modern industrialization, transportation and domestic activities. Hence, many researchers are working to upgrade novel energy resources alternative to fossil fuels. ${ }^{2)}$ Furthermore, these resources are derived from inexpensive and easily or nearby available non-food materials. Every year, about 100 billion metric tons (BMTs) of biomass wastes are produced from various agricultural, forestry and industrial resources and these biomass materials could be utilized as promising bioenergy sectors worldwide. ${ }^{3)}$ The production of biomass wastes (in Mt: million tons), originated from various agricultural sources are rice straw (731 Mt), wheat straw (354 Mt), corn straw (204 $\mathrm{Mt})$, sugarcane bagasse $(181 \mathrm{Mt})$ and rice husk $(110 \mathrm{Mt})$ as well as around $73 \mathrm{Mt}$ of forestry residues (during harvesting and product processing). ${ }^{4,6)}$ Traditionally, the biomass and its residues have been widely utilized as significant bioenergy and bioproduct producing resources, around $10 \sim 14 \%$ of the global energy demands have been fulfilled from biomass supplies. ${ }^{7,8}$ Approximately $25 \%$ of biomass bioenergy are widely utilized in industries for power generations and remaining $75 \%$ is used for household heat generation (cooking and firing) activities. During the photosynthesis process, the green plants (chlorophyll) react with water (in the atmosphere) to produce electrons $\left(\mathrm{e}^{-}\right)$and protons $\left(\mathrm{H}^{+}\right)$and use them to turn $\mathrm{CO}_{2}$ (in the atmosphere) in the presence of solar radiant energy (as a catalyst) into energy rich chemical products (glucose or carbohydrate) and release $\mathrm{O}_{2}$ (as a waste product) as:

$$
\begin{aligned}
& \underset{\text { (Chlorophyll) }}{\text { Biomass or Green plants }}+\underset{\text { (from atmosphere) }}{6 \mathrm{CO}_{2}(\mathrm{~g})+6 \mathrm{H}_{2} \mathrm{O}(\mathrm{g})} \stackrel{\text { Solar energy }}{\stackrel{\text { (as catalyst) }}{\longrightarrow}} \\
& \mathrm{C}_{6} \mathrm{H}_{12} \mathrm{O}_{6}(\mathrm{~s})+6 \mathrm{O}_{2}(\mathrm{~g}) \\
& \text { (Energy rich product)(Waste product) }
\end{aligned}
$$

Though, the energy producing biomasses have been widely utilized in major of the bioenergy production sectors, an alternative to conventional fossil fuel energy resourced demands behind the coal, crude oil or petroleum and natural gases $^{8-12)}$, there are certain impacts of biomass based bioenergy production on the water quantity and quality, followed by GHG (greenhouse gas) emissions, and erosion of soil organic carbon (SOC). Furthermore, the publications related to energy producing biomasses and their impacts on our environment imply that some awareness should be given towards protection of the environment while supporting the expansion of biomass based bioenergy developement. ${ }^{13)}$ This review focuses on various types of biomass resources, biomass conversion technologies, advantages and disadvantages of biomass materials and the environmental impact of bioenergy production on water, air and soil and protection measurement.

\section{Types of Biomass resources}

Generally, biomass sources are organic matter and containing $\mathrm{C}, \mathrm{H}$ and $\mathrm{N} / \mathrm{O} / \mathrm{S}$, derived from any type of plants as well as animal species of the biosphere. According to the IEA (International Energy Agency), the biomass and its materials are derived from biogenic sources, mainly animals and plants from wood and agricultural crops, and organic wastes from municipal and agro-industry. ${ }^{14)}$ The classification of biomass materials has been approached, based on some important facts like their life cycle, origin, fibrous nature, aquatic/terrestrial nature and yield. Based on the origin, the biomass sources are further classified into three types as are illustrated in Table $\mathbf{1}^{15)}$ :

- Organic residues and wastes: include agriculture and forestry residue (e.g. Trees, wood, wood waste, dung, manure, poultry waste), municipal waste (e.g. Food waste, yard clippings, refuse derived fuel, kitchen waste, biosludge) and industrial residues (e.g. Sawdust, timber slash, mill scrap, brewery by-products, oil extraction meal). ${ }^{11,15-20)}$

- Lignocellulosic residues: such as switchgrass, miscanthus, alfalfa, Altai wildrye. ${ }^{15)}$

- Product from agriculture: such as palm oil, jatropha, soybean, mustards, sunflower, coconut. ${ }^{15)}$

Biomass material resources can be categorized as traditional and new (modern) biomasses, based on the energy sector utilization. Traditional biomasses are used as non-commercial sources (e.g. Food cooking), whereas the new biomasses (e.g. Methane and ethanol generation from biomass) ${ }^{16,21)}$ are effeicient commercial sources. Moreover, the increasing utilization of biomass source as a promising future bioenergy sector could 
Table 1. Classification of biomass materials according to their origin (Adopted and modified (Refs. ${ }^{14,15}$ ).

\begin{tabular}{|c|c|c|}
\hline \multicolumn{2}{|c|}{ Biomass category } & Biomass materials \\
\hline \multirow[t]{3}{*}{ Agriculture } & Sugar & Sugarcane, corn, sweet sorghum \\
\hline & Starch & Mazie or Corn, cassava, sweet potato \\
\hline & Oil seed crops & Rapeseed, palm oil, jatropha, soybean, mustards, sunflower, coconut \\
\hline $\begin{array}{l}\text { Lignocellulosic plants short } \\
\text { rotation coppice }\end{array}$ & Tropical grasses & Poplar, sycamore, switchgrass, Miscanthus, alfalfa, Altai wildrye, sweet clover \\
\hline \multirow[t]{3}{*}{ Organic residues and wastes } & Industrial residues and waste & $\begin{array}{l}\text { Straw, bagasses, husks, shells, wood shaving, sawdust, fiber sludge, brewery } \\
\text { by-products, oil extraction meal, cross-cut ends, plywood by-products }\end{array}$ \\
\hline & $\begin{array}{l}\text { Agriculture and forestry } \\
\text { residue }\end{array}$ & $\begin{array}{l}\text { Stumps, whole tree, bark, shrubs, slabs, logging by-products, dung, manure, } \\
\text { poultry waste }\end{array}$ \\
\hline & Municipal waste & Slaughterhouse byproducts, kitchen waste, biosludge \\
\hline
\end{tabular}

act as the chief emerging alternative resources to fossil fuel, to reduce the GHGs emission and also foster bioeconomy. During the thermochemical (combustion, co-firing, gasification, hydrothermal liquefaction, pyrolysis) and biological (anaerobic digestion, alcohol fermentation) conversion processes the biomass materials containing, high percentage of $\mathrm{O}$ and low percentage of $\mathrm{C}$ and $\mathrm{H}$ contents have been converted to different form of sustainable energies in he form of solid (biochar) or liquid (bio-oil or biofuel, bioethanol, biodiesel) or gaseous (bio- $\mathrm{H}_{2}$, bio- $\mathrm{CH}_{4}$, bio-syngas) fuels, electric power, heat energy and useful cost-effective high value added bioproducts towards biochemical, biochip, biofertilizer, biopolymer industries. ${ }^{8,22,23)}$

\section{Biomass Conversion to biofuels}

The production of bioenergy and biofuels from various biomass materials have been classified, according to the type of biomass materials and their residues utilized. ${ }^{15,20,24,25)}$ Fuels generated through biomass are classified as first, second, third, fourth generation biofuels.

\subsection{First generation (1G) biofuels}

First generation $(1 \mathrm{G})$ biofuels are generated from different types of food crops (rice, wheat, rapeseed, sorghum, sugarcane, corn). Biodiesel and bioethanol are the primary first generation $(1 \mathrm{G})$ biofuels. ${ }^{17)}$ In 2015 , the USA (14.81 billion gallons) and Brazil (7.09 billion gallons) produced around $85 \%$ of the global bioethanol. ${ }^{15)}$ The USA uses corn biomass as a primary source for bioethanol generation, whereas Brazil uses mainly sugar cane. ${ }^{15,17)}$ In the Europe Union sugar beet and starch crops represent the primary sources of bioethanol production (around 3.44 billion liters). ${ }^{17}$

Biodiesel has been generated from oilseed crops (palm oil, soybean, sunflower, canola). ${ }^{15,17)}$ In 2006, the world's biodiesel generation was reached more than 6 billion liters. The largest biodiesel producer is Germany with 2.5 billion liters, primarily derived from sunflower and rapessed. The second largest producer is the USA, which produces 0.86 billion liters, overall the biodiesel generation has been increased in some countries (France, Austria, Italy). ${ }^{17)}$

However, primary biomasses for the first generation biofuels pose a significant issue while the production of biofuels depends on the food crops supplies and their cost.

\subsection{Second generation (2G) biofuels}

The second generation $(2 \mathrm{G})$ biofuels are generated from lignocellulosic biomass (containing $30 \sim 50 \%$ of cellulose, $15 \sim 35 \%$ of hemicellulose and $10 \sim 20 \%$ of lignin) and their residues, derived from the agriculture (straw, corn stover, sugar bagasse, vegetative grasses, wood along with their wastes, energy crops and their residues), forest residues. The production of second generation biofuels from lignocellulosic biomass solves the problem of food competitiveness related to the use mainly of sugar cane and corn as feedstocks for the production of first generation biofuels. ${ }^{15,17)}$

\subsection{Third generation (3G) biofuels}

The engineered algae are a rich energy source and is widely utilized for third generation biofuels production either directly or through some conversion process. In addition, algal species have high sugar or lipid or oil contents with a high growth rate as well as it is easily cultivated in lagoons or open ponds, under specific conditions and not at all influence the food production in the land areas. ${ }^{24)}$ Hence, the production of bioenergy from the algal feedstock is considered as a future energy source and potentially replaces fossil fuel demands. 
Table 2. Various biomass conversion technologies (BCT), process, bioenergy products, advantages and disadvantages (Adopted and modified Refs. ${ }^{24,27)}$ ).

\begin{tabular}{|c|c|c|c|c|}
\hline $\begin{array}{l}\text { Conversion } \\
\text { technologies }\end{array}$ & Processes & $\begin{array}{l}\text { Bioenergy } \\
\text { products }\end{array}$ & Advantages & Disadvantages \\
\hline $\begin{array}{l}\text { Thermal } \\
\text { conversion } \\
\text { method }\end{array}$ & $\begin{array}{l}\text { Combustion } \\
\text { Co-firing or } \\
\text { Co-combustion } \\
\text { Pyrolysis } \\
\text { Torrefaction }\end{array}$ & $\begin{array}{l}\text { Heat / steam } \\
\text { Oil and biochar } \\
\text { Biocoal }\end{array}$ & $\begin{array}{l}\text { - Biomass can be co-fired with existing } \\
\text { fossil fuel power stations. } \\
\text { - Use to operate the steam turbine to } \\
\text { produce electricity. } \\
\text { - Can be operated at optimum } \\
\text { temperature range. }\end{array}$ & $\begin{array}{l}\text { - Specific temperature and control system is } \\
\text { needed. } \\
\text { - Emission of hazardous gases is expected. }\end{array}$ \\
\hline $\begin{array}{l}\text { Chemical } \\
\text { conversion } \\
\text { method }\end{array}$ & Direct conversion & Biodiesel & - Advanced biofuels can be obtained & $\begin{array}{l}\text { - Energy input for agriculture and feed stock } \\
\text { production reduced. } \\
\text { - Large scale conversion operations } \\
\text { required. }\end{array}$ \\
\hline $\begin{array}{l}\text { Thermo-chemical } \\
\text { conversion } \\
\text { method }\end{array}$ & $\begin{array}{l}\text { Pyrolysis } \\
\text { Carbonization } \\
\text { Gasification } \\
\text { Hydrothermal } \\
\text { conversion } \\
\text { Catalytic } \\
\text { liquefaction }\end{array}$ & $\begin{array}{l}\text { Synthesis gas } \\
\text { Jet fuel } \\
\text { Diesel }\end{array}$ & $\begin{array}{l}\text { - Cheap, easy to transport and easy to } \\
\text { store. } \\
\text { - Large quantity of charcoal and } \\
\text { associated products can be produced. } \\
\text { - Less processing required to produce } \\
\text { marketable products. } \\
\text { - High quality products of greater energy } \\
\text { density can be produced. }\end{array}$ & $\begin{array}{l}\text { - Heat is required to produce a synthesis gas. } \\
\text { - High investment cost is required. } \\
\text { - Technical problems are so far limited. }\end{array}$ \\
\hline $\begin{array}{l}\text { Biochemical } \\
\text { conversion } \\
\text { method }\end{array}$ & $\begin{array}{l}\text { Anaerobic } \\
\text { digestion } \\
\text { Fermentation }\end{array}$ & $\begin{array}{l}\text { Transport fuels } \\
\text { Gas energy } \\
\text { Renewable } \\
\text { chemicals }\end{array}$ & $\begin{array}{l}\text { - Applicable in microbial engineering. } \\
\text { - Less potent to GHG in the atmosphere. } \\
\text { - Make use of the energy in the gas. } \\
\text { - Reduce the volume of sludge to be } \\
\text { disposed for facilitating proper } \\
\text { disposal. } \\
\text { - Economically competitive in the } \\
\text { medium term. }\end{array}$ & - Health threat to people and livestock \\
\hline
\end{tabular}

\subsection{Fourth generation ( $4 G$ ) biofuels}

Fourth generation biofuels increase the production of biofuels, using some metabolically engineered species (engineered algae, bacteria, some other microbes), combining $\mathrm{CO}_{2}$ capture and energy storage capability. During the production of biofuels, some of the species have high percentage of lipid content, which can be further degraded into high value added bioproducts like polymeric hydrocarbons or petroleum products. ${ }^{24,25)}$

\section{Biomass conversion technologies}

During the conversion technologies, the biomass materials or residues are converted into specific bioenergy with high value added bioproducts. Several types of biomass conversion technologies (BCT) have been employed for obtaining bioenergy and bioproducts. ${ }^{17,25-28)}$ The advantages and disadvantages of the conversion technologies are summarized in Table $2^{25,28)}$

\subsection{Thermochemical conversion:}

Heating coupled chemical processes are mainly utilized to produce bioenergy from biomass materials. During the thermochemical conversion, the biomass material is treated at high temperature to produce solid (biochar), liquid (high oxygenated bio-oil), and gaseous (syngas) form of bioenergies. The main thermochemical conversion methods are gasification and pyrolysis. In gasification technology, the biomass is converted to syngas containing $\mathrm{CO}_{2}, \mathrm{CO}, \mathrm{H}_{2}$ and $\mathrm{CH}_{4}$. The gasification process is performed at very high temperature (over $600^{\circ} \mathrm{C}$ ) with lower oxygen content in a gasifier reactor. ${ }^{29)}$ Syngas are used as stationary biofuels or for ethanol, diesel and ethanol through Fischer-Tropsch conversion. ${ }^{15,25)}$ Pyrolysis process provides the biomass conversion at an average temperature of about $300 \sim 600^{\circ} \mathrm{C}$ and in the absence of oxygen to liquid (bio-oil), solid (shar) and gas. The proportions of such products are depending on the feedstock type, heating level and residence time. ${ }^{30}$

\subsection{Thermal conversion}

During thermal process heat (exothermic) energy is utilized for converting biomass into bioenergy, this technology and include direct combustion, co-firing, pyrolysis and torrefaction. Industrially, several types of biomass materials like wood, 
agricultural residues, wood pulping liquor, MSW, can be burnt or combusted directly to produce heat and generation of electric power (renewable energy source). However, this method it's not effectively utilized, due to high percentage of ash formation during combustion of most of the biomass materials.

\subsection{Biochemical conversion}

Enzymes, bacteria or other microbes are used for converting biomass into biofuels, it includes anaerobic digestion and alcohol fermentation. During the fermentation process, the microorganisms interact with sugar based (sugarcane, sweet sorghum) as well as starch based (corn grain) biomasses into recoverable bioproducts (bioethanol). The obtained bioethanol is further used for the production of biopolymers (polyethylene) or blended with gasoline (E15). ${ }^{25,31)}$ Anaerobic digestion (AD) process consists the breakdown of biodegradable biomass into biogas by microorganisms at a temperature, ranging between 30 and $65^{\circ} \mathrm{C}$, but there is no air ${ }^{17,32-34)}$, these biogas cam be considered as an alternative to natural gas.

\subsection{Microbial electrochemical technologies (METs)}

Currently, the main global agenda issues are the energy and freshwater. ${ }^{35)}$ Waste and wastewater treatment can be an important resource for bioenergy production and environmental pollution removal. ${ }^{36}$ ) Several wastewater technologies are used to provide the energy requirement, such as anaerobic digestion and heat pumps. ${ }^{35)}$ Newly, microbial electrochemical technologies (METs) have been developed for the energy extraction and producing valuable chemicals from wastewater, using electrically active bacteria (EAB). ${ }^{37}$ METs process provides significant advantages, including power recovery in various forms and less sludge production over the conventional biological treatment technologies. ${ }^{35)}$ The METs process can be classified to: microbial fuel cell (MFC), microbial desalination cells (MDC) and microbial electrolysis cell (MEC).

\subsubsection{Microbial fuel cell (MFC)}

The microbial fuel cell (MFC) process allows the transformation of organic matter to bioelectricity through electrochemically active bacteria $(\mathrm{EAB}){ }^{38)}$ EAB oxidizes organic matter, causing release of electrons. The MFC includes an anode chamber, a cathode chamber which are separated by an ion exchange membrane (IEM). ${ }^{39)}$ In MFC, the releasing electrons and protons are resulting from the organic matter oxidation by $\mathrm{EAB}$ at the anode chamber which are passed to the cathode by the external circuit and the IEM, respectively. ${ }^{36,37)}$ The flow of electrons leads to electricity production. ${ }^{36)}$

\subsubsection{Microbial desalination cell (MDC)}

Microbial desalination cell (MDC) is suitable for bioelectric energy generation from the wastewater and simultaneously desalinating seawater. ${ }^{35}$ ) The MDC can be constructed, when an extra chamber is added between the anode and cathode chamber in the MFC. ${ }^{40)}$ MDC includes an anode chamber, a cathode chamber, an anion exchange membrane (AEM) and cation exchange membrane (CEM). ${ }^{40)}$ In MDC, EAB oxidizes organic matter to electrons and protons at the anode. ${ }^{35)}$ The free electrons are subsequently passed to the cathode by the external circuit. ${ }^{35,40)}$ The anions $\left(\mathrm{Cl}^{-}\right)$can be transported to the anode through the AEM and simultaneously the cations $\left(\mathrm{Na}^{+}\right)$get transported to the cathode through the CEM, concurrently with the electros transfers. ${ }^{41)}$ This system allows a simultaneous electricity generation and water desalination without additional any energy sources. ${ }^{35)}$

\subsubsection{Microbial electrolysis cell (MEC)}

The microbial electrolysis cell (MEC) provides biohydrogen generation and wastewater treatment. ${ }^{40)}$ The MEC process configuration are similar to that of MFC, the difference is an external voltage is applied and the cathode are maintained in anaerobic environment. ${ }^{40)}$ In a MEC, the BAEs present in the anode oxidizes the organic matter to electrons, the released electrons are transferred to the cathode via a separator and are reduced to biohydrogen. ${ }^{41)}$ Recently, MECs have gained attention extensively among the researchers that obviously represents nearly about $75 \%$ publication in this field. ${ }^{42,47)}$

\section{Advantages and disadvantages of biomass materials}

With a rapid increase in the productions of biomass based bioenergy and bioproducts as they possess numerous advantages (i) biomass is a direct source of clean energy, (ii) it is an ultimate as well as continual alternative to fossil fuel resources, (iii) the source materials are easily and available in huge amounts and cheaper than fossil fuel materials, (iv) the integrated biorefineries of industrial wastes as well as other feedstocks produce high added value biochemicals, biofuels and biopolymers, (v) low content of $\mathrm{S}$ and $\mathrm{N}$ (i.e., less emission of $\mathrm{SO}_{\mathrm{x}}$ and $\mathrm{NO}_{\mathrm{x}}$ to the environment), (vi) significant calorific values as compared to fossil fuels, (v) does not 
Table 3. Conversion of various biomass materials into bioenergy products and their sustainability aspects (Adopted and modified Ref. $^{24)}$ ).

\begin{tabular}{|c|c|c|c|c|c|}
\hline \multirow{2}{*}{ Biomass materials } & \multirow{2}{*}{ Bioenergy products } & \multirow{2}{*}{ Country } & \multicolumn{3}{|c|}{ Objective or Sustainability aspects ${ }^{\mathrm{a}}$} \\
\hline & & & Economic & Environmental & Social \\
\hline Biomass waste and residues & Bioethanol & Iran & Min. annual cost & & \\
\hline Sugarcane and eucalyptus & Bioethanol & Brazil & Min. total production cost & & \\
\hline Corn & Bioethanol & China & Min. life cycle cost & & \\
\hline Castor oil & Biodiesel & Brazil & $\begin{array}{l}\text { Min. investment cost and } \\
\text { min. logistical cost }\end{array}$ & & \\
\hline Corn stover & Drop-in fuel & United States & Min. total production cost & & \\
\hline Biomass & Biodiesel & United States & Max. total profit & & \\
\hline $\begin{array}{c}\text { Cellulosic biomass and municipal } \\
\text { solid waste (MSW) }\end{array}$ & Bioethanol & United States & Min. total cost & & \\
\hline Switchgrass & Bioethanol & United States & Min. annual cost & & \\
\hline $\begin{array}{l}\text { Crop residues, energy crops and } \\
\text { wood residues }\end{array}$ & $\begin{array}{c}\text { Gasoline, } \\
\text { diesel and jet fuel }\end{array}$ & United States & Min. annual cost & & \\
\hline Miscanthus & Bioethanol & United States & Min. annual cost & & \\
\hline $\begin{array}{l}\text { Crop residues, energy crops and } \\
\text { wood residues }\end{array}$ & $\begin{array}{c}\text { Gasoline, } \\
\text { diesel and jet fuel }\end{array}$ & United States & Min. unit cost & & \\
\hline Switchgrass & Bioethanol & United States & Max. the SC profit & & \\
\hline $\begin{array}{l}\text { Wheat, wheat straw and } \\
\text { miscanthus }\end{array}$ & Bioethanol & United Kingdom & Min. the $\mathrm{SC}$ cost & & \\
\hline Forestry biomass & Biooil & United States & Max. expected SC profit & & \\
\hline Corn stover and wood residues & Biodiesel & United States & Min. the biofuel cost & & \\
\hline Vegetable oil & Biodiesel & Greece & Max. the total value & & \\
\hline $\begin{array}{l}\text { Crop, forestry biomass, animal } \\
\text { fats, waste grease and MSW }\end{array}$ & Biooil & United States & Max. SC profit & & \\
\hline Forestry biomass & Biooil & United States & Min. SC cost & & \\
\hline Crop residue & Bioethanol & United States & Max. NPV & & \\
\hline Corn & Bioethanol & Italy & Max. NPV & & \\
\hline Biomass & Bioethanol & United States & Min. the SC cost & & \\
\hline Miscanthus & Bioethanol & United States & Min. annual production & & \\
\hline Switchgrass & Biobutanol & United States & Max. NPV & & \\
\hline Woody biomass & Biodiesel & United States & Min. the SC cost & & \\
\hline Energy crop & Bioethanol & United States & Min. SC cost & & \\
\hline Animal waste & Syngas / Bio- $\mathrm{H}_{2}$ & Finland & Max. SC profit & & \\
\hline $\begin{array}{l}\text { Biowastes, sludges, agricultural } \\
\text { residues and energy crops }\end{array}$ & Biogas & United States & Min. total distance & & \\
\hline $\begin{array}{l}\text { Animal waste, corn stover and } \\
\text { forest residues }\end{array}$ & $\begin{array}{l}\text { Natural gas, gasoline } \\
\text { and diesel }\end{array}$ & United States & Max. profit & & \\
\hline Sugarcane bagasses & Bioethanol & Mexico & Max. profit & Min. eco-points & $\begin{array}{l}\text { Max. job } \\
\text { creations }\end{array}$ \\
\hline Wood residues & Biooil and pellets & Canada & Max. NPV & Max. GHG saving & $\begin{array}{l}\text { Max. job } \\
\text { creations }\end{array}$ \\
\hline $\begin{array}{l}\text { Wheat, wheat straw and } \\
\text { miscanthus }\end{array}$ & Bioethanol & Canada & Min. total daily cost & Min. GHG & \\
\hline $\begin{array}{l}\text { Crop residues, energy crop and } \\
\text { wood residues }\end{array}$ & Gasoline and diesel & United Kingdom & Min. annual cost & Min GHG & \\
\hline $\begin{array}{l}\text { Crop residues, energy crop and } \\
\text { wood residues }\end{array}$ & Bioethanol & United States & Min. annual cost & Man life cycle GHG & $\begin{array}{l}\text { Max. } \\
\text { accrued jobs }\end{array}$ \\
\hline Woody biomass & - & Austria & Max. profit & Min. $\mathrm{CO}_{2}$ emission & \\
\hline
\end{tabular}


Table 3. Continued

\begin{tabular}{|c|c|c|c|c|c|}
\hline \multirow{2}{*}{ Biomass materials } & \multirow{2}{*}{ Bioenergy products } & \multirow{2}{*}{ Country } & \multicolumn{3}{|c|}{ Objective or Sustainability aspects ${ }^{a}$} \\
\hline & & & Economic & Environmental & Social \\
\hline Woody biomass & Biooil & United States & Max. 20 year profit & Min. GHG & \\
\hline Palm oil & Biodiesel & Colombia & Min SC cost & Min. GHG & \\
\hline Corn grain and corn stover & Bioethanol & Italy & Max NPV & $\begin{array}{l}\text { Min. water } \\
\text { footprints / } \\
\text { Min. GHG }\end{array}$ & \\
\hline Corn grain and corn stover & Bioethanol & Italy & Min. SC cost & Min GHG & \\
\hline $\begin{array}{c}\text { Woody biomass, sugarcane, corn } \\
\text { grain, sorghum grain, sweet } \\
\text { sorghum, African palm, jatropha, } \\
\text { safflower }\end{array}$ & $\begin{array}{l}\text { Bioethanol, biodiesel, } \\
\text { butanol and xylitol }\end{array}$ & Mexico & Max. SC profit & Min. eco-points & $\begin{array}{l}\text { Max. job } \\
\text { creations }\end{array}$ \\
\hline $\begin{array}{c}\text { Woody biomass, sugarcane, corn } \\
\text { grain, sorghum grain, sweet } \\
\text { sorghum, African palm, jatropha, } \\
\text { safflower }\end{array}$ & $\begin{array}{c}\text { Bioethanol and } \\
\text { biodiesel }\end{array}$ & Mexico & Max. SC profit & Min. eco-points & $\begin{array}{l}\text { Max. job } \\
\text { creations }\end{array}$ \\
\hline Sugarcane & Bioethanol & & Max. NPV & $\begin{array}{l}\text { Min. Eco-indicator } \\
99 \text { / GWP100 }\end{array}$ & \\
\hline Animal manure and energy crop & Biogas & Turkey & Max. SC profit & $\begin{array}{l}\text { Min. weighted } \\
\text { unused waste } \\
\text { biomass }\end{array}$ & \\
\hline Lignocellulosic biomass & Bioethanol & Iran & & $\begin{array}{l}\text { Min. Eco-indicator } \\
99\end{array}$ & $\begin{array}{l}\text { Max. job } \\
\text { creations }\end{array}$ \\
\hline Waste cooking oil & Biodiesel & China & Max. profit & $\begin{array}{l}\text { Max. carbon } \\
\text { emission allowance }\end{array}$ & $\begin{array}{l}\text { Max. social } \\
\text { responsibility }\end{array}$ \\
\hline Corn and cellulosic biomass & Bioethanol & United States & Min. total system cost & & \\
\hline Biomass & Gasoline & United States & Max. annual profit & & \\
\hline Corn stover and forest residues & Bioethanol & United States & $\begin{array}{c}\text { Min. expected total system } \\
\text { cost }\end{array}$ & & \\
\hline Biomass & Bioethanol & Iran & Max. biorefinery profit & & \\
\hline $\begin{array}{l}\text { Agricultural residues, energy crops } \\
\text { and wood residues }\end{array}$ & Hydrocarbon fuels & United States & Min. annual cost & & \\
\hline $\begin{array}{l}\text { Lignocellulosic biomass, forest } \\
\text { residues and MSW }\end{array}$ & Bioethanol & United States & Min. expected SC cost & & \\
\hline Corn grains and corn residues & Gasoline & United States & Max. annual profit & & \\
\hline Corn & Bioethanol & United States & Max. SC profit & & \\
\hline Corn & Gasoline and diesel & United States & Max. SC profit & & \\
\hline Sugarcane & Bioethanol & United States & Max. total net profit & & \\
\hline Forest residues & Bioil & United States & Max. annual profit & & \\
\hline Biomass & Bioethanol & United States & Min. SC profit & & \\
\hline Animal waste & Syngas / Hydrogen & United States & Max. SC profit & & \\
\hline Corn stover and forest residues & Bioethanol & Central European & Min. in the SC cost & & \\
\hline $\begin{array}{l}\text { Corn, corn stover, wood chips, } \\
\text { MSW, manure and timber }\end{array}$ & Bioethanol & United States & Max. SC profit & $\begin{array}{l}\text { Min. environmental } \\
\text { footprints }\end{array}$ & $\begin{array}{l}\text { Max. social } \\
\text { footprints }\end{array}$ \\
\hline
\end{tabular}

a SC: Supply chain; NPV: Net precent value; GHG: Green house gas; Min.: Minimum; Max: Maximum.

increase the $\mathrm{CO}_{2}$ emission in the biosphere, it also acts as a carbon-neutral or green house neutral energy resources, i.e., burning or combustion of any biomass material releases carbon (as $\mathrm{CO}_{2}$ or greenhouse gas) to the environment and then $\mathrm{CO}_{2}$ is absorbed for their growth of all the greenish plants (biomass) during their life cycle, as a result, the net balance amount of $\mathrm{CO}_{2}$ emission and its absorption to the atmosphere is maintained as zero or neutral throughout the usage cycle of biomass, (vi) reduces the quantity of waste in landfills. ${ }^{45,47)}$ However, discharge of immense amount of $\mathrm{CO}_{2}$ gas along with particulates by direct burning of biomass materials have some negative impact of human health and the environment. ${ }^{48,49)}$ 


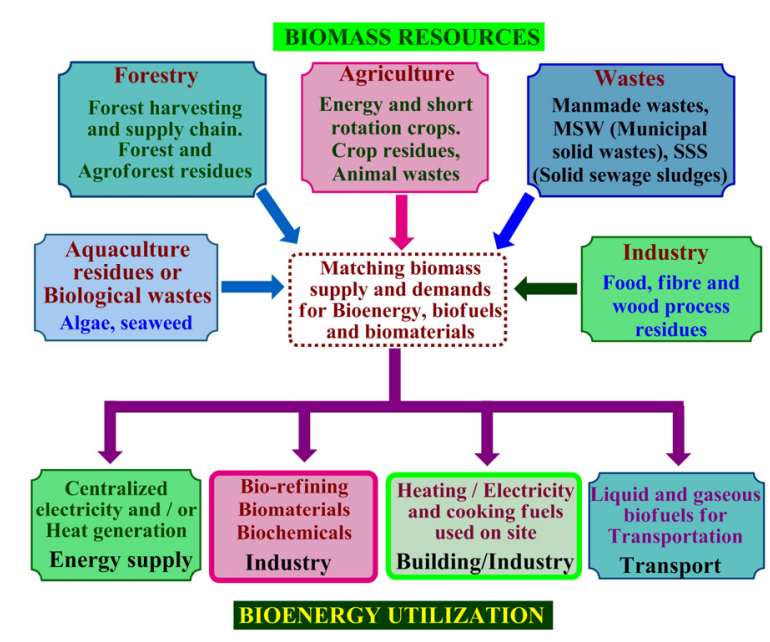

Fig. 1. Various biomass conversion paths from bioresource into bioenergy products(Adopted and modified Refs. ${ }^{19,20)}$ ).

Hence, some of the challenges towards the utilization of biomass material resources and considerations about $\mathrm{CO}_{2}$ emission can be recapitulated as,

- Shortage of clean and green traditional biomasses and land availability for energy producing purposes,

- Identification of novel biomass sources,

- Optimization in the production of bioenergy or biofuel techniques with requirement of minimum energy, maximum transportability, and compliance with handling equipment in power plants.

- The developed bioprocesses permit extraction of numerous phosphorous like nutrients the developed bioprocesses permit extraction of numerous nutrients

- Development on various combinations in conversion or biorefinery processes,

- results in the need to extract numerous high added value byproducts.

\section{Impact of Bioenergy Production on the Environment}

The impact of biomass bioenergy on the environment has gradually been increased, the term "water quantity and quality" occupied first place (16\%), consequently by emissions of GHGs (6\%), followed by SOC (5\%), in the year of 2017.

\subsection{Impact on water}

Hoekman et al. $^{50)}$ and Zhou et al. ${ }^{51)}$ illustrated that consumption of water by corn biomass and utilization and conversion of the land, mostly from its native form to perennial grasslands like miscanthus and switchgrass. This consumption also considerably and directly affects the hydrological processes, namely ET (evapotranspiration), quantity of water content in soil, surface runoff, total water content, and at a regional scale for the production of the first-generation ethanol biofuel (100 million gal/year). They found consequently that stress in water scales as that crop needs more water during its cultivation when compared to other crops like wheat and soybean, particularly in its joining stage that varies with watershed and harvest rate. ${ }^{52)}$ Guo et al. ${ }^{53)}$ proposed that such land transition for energy producing crops, at the watershed scale may cause diminution of water resources. Similarly, in the case of water quality there is a big concern towards nutrients pollution, mainly by nitrate that may be caused by surface runoff and infiltration to groundwater. ${ }^{54)}$ It may be reduced by following rotational cultivation of corn and soybean ${ }^{55)}$ and cultivating perennial grasses, which all can effectively reduce nearly $30 \sim 40 \%$ of the total nitrogen. ${ }^{53,56)}$ Qin et al. ${ }^{57)}$ suggested that it is possible to reduce and balance such issues by selecting and cultivating proper crop species with optimal management like appropriate fertilization, irrigation, and rate of harvesting.

\subsection{Impact on air}

The land transition to bioenergy feedstock production mainly impacts on the main components of the GHGs such as $\mathrm{CO}_{2}$ and $\mathrm{N}_{2} \mathrm{O}{ }^{58)}$ Harris et al. ${ }^{59)}$ suggested that the conversion of arable land for cultivating second generation bioenergy crops could lead to a small diminution of $\mathrm{CO}_{2}$ emission to the atmosphere, while native grassland land transition to cultivating the first generation bioenergy crops and short rotation coppice (SRC) demonstrates an increase in emission of $\mathrm{CO}_{2}$. Consequently, some considerations should be given to select appropriate bioenergy crops along with keen management practices to mitigate the emission of $\mathrm{CO}_{2}$. Similarly, Harris et al. ${ }^{59)}$ also revealed that conversion of the arable land to SRC as well as perennial grasses could reduce the emission $\mathrm{N}_{2} \mathrm{O}$ also $(-0.2 \mathrm{t} /$ ha year). While, the transition of the grassland to $\mathrm{SRC}$, nitrogen manure application and ethanol biofuel production could make a slight increase in $\mathrm{N}_{2} \mathrm{O}$ emission. Thereby, they concluded that selection of land location can minimize and control the $\mathrm{N}_{2} \mathrm{O}$ emissions considerably.

\subsection{Impact on soil}

The quality of the soil has been determined by soil organic carbon (SOC), which is the significant soil index. The SOC only benefits water retention, soil biodiversity, and crop 
productivity of the soil. While producing biomass based bioenergy, three facts viz. removal of residues, tillage practices, and utilization of land strongly influences the SOC via soil disturbance. Hoekman et al. ${ }^{50)}$ predicted that there is a direct stimulation in loss of SOC during, harvesting of dead plant residues i.e., removal of residues. It is attributed to an abnormally reduced carbon input, which can be controlled by optimization in removal of residues, addition of nutrient rich fertilizers and biochar. ${ }^{60)}$ Overall, Li et al. ${ }^{61)}$ and Pourhashem et al. ${ }^{62)}$ predicted that such practices not only accumulate the SOC but also the elemental carbons in the form of $\mathrm{CO}_{2}$ of the air, which is due to electronegativity of the organic aggregate. Management of tillage practices for SOC can be simulated using a biogeochemical model, proposed by Drewniak et al. ${ }^{63)}$ McCalmont et al. $^{64)}$ have done SOC sequestration to minimize the loss, at the time of transition of arable land to perennial grasses. They emphasized that arable land utilization for Miscanthus can accumulate organic carbons with a sequestration rate of about $0.42 \sim 3.8 \mathrm{Mg} \mathrm{C} / \mathrm{ha}$ year. Further, mitigation of $\mathrm{NO}_{\mathrm{x}}$ and $\mathrm{CH}_{4}$ could nourish not only the soil carbon sink but also the air quality protection. ${ }^{62)}$

\section{Conclusion}

It is to be expected that there might be substantial growth in the production of biomass based energy over the next 20 years. It has been observed that there is a potential tremendous increase towards such production. For instance, by the year 2030 it is estimated that biomass based energy from the waste residues and energy crops in EU may range from 4.4 to 24 EJ. The biomass based bioenergy is an alternative to fossil fuels and provides an essential contributor to the global energy security due to their availability and renewability. This review summarizes various types of biomass, its conversion technology, advantages and disadvantages and environmental impacts of bioenergy production on water, air and soil along with protection measures. Based on the published reports, it is advisable to provide great attention to issues on quantity and quality of water amongst the other influencing terms while producing biomass based bioenergy. Emissions of GHGs and SOC are the other two adverse effects on the environment which all mainly depend on types of biomass, land sources and optimal management practices. Hence, predicting the apparent areas for cultivation, a suitable type of crops, and management practices, we can favor both the production of biomass based bioenergy and our environment.

\section{References}

1. Y. WU, F. Zhao, S. Liu, L. Wang, L. Qiu, G. Alexandrov, V. Jothiprakash, Bioenergy production and environmental impacts, Geosci. Lett., 5(1), 14(2018).

2. C. Zou, Q. Zhao, G. Zhang, B. Xiong, Energy revolution: from a fossil energy era to a new energy era, Nat. Gas. Ind. B., 3(1), 1-11(2016).

3. TerraGreen, Global Waste - Solvable Problem as a Renewable Energy Resource, https://medium.com/@support_61820/global -waste-solvable-problem-as-a-renewable-energy-resource-5d8f 05cc1a7d, September(2020).

4. A. A. Koutinas, A. Vlysidis, D. Pleissner, N. Kopsahelis, I. L. Garcia, I. K. Kookos, S. Papanikolaou, T. H. Kwan, C. S. K. Lin, Valorization of industrial waste and by - product streams via fermentation for the production of chemicals and biopolymers, Chem. Soc. Rev., 43(8), 2587-2627(2014).

5. N. Sarkar, S. K. Ghosh, S. Bannerjee, K. Aikat, Bioethanol production from agricultural wastes: an overview, Renewable Energy, 37(1), 19-27(2012).

6. E. J. Cho, L. T. P. Trinh, Y. Song, Y. G. Lee, H-J. Bae, Bioconversion of biomass waste into high value chemicals, Bioresour. Technol., 298, 122386(2020).

7. L. Axelsson, M. Franzén, M. Ostwald, G. Berndes, G. Lakshmi, N. H. Ravindranath, Perspective: jatropha cultivation in southern India: assessing farmers' experiences, Biofuel. Bioprod. Biorefin., 6(3), 246-256(2012).

8. A. Ahmed, M. S. A. Bakar, R. Hamdani, Y-K. Park, S. S. Lam, R. S. Sukri, M. Hussain, K. Majeed, N. Phusuntif, F. Jamil, M. Aslam, Valorization of underutilized waste biomass from invasive species to produce biochar for energy and other value - added applications, Environ. Res., 186, 109596(2020).

9. A. Ahmed, M. S. A. Bakar, A. K. Azad, R. S. Sukri, T. M. I. Mahlia, Potential thermochemical conversion of bioenergy from Acacia species in brunei darussalam: a review, Renewable Sustainable Energy Rev., 82(3), 3060-3076(2018).

10. T. A. Mamvura, G. Danha, Biomass torrefaction as an emerging technology to aid in energy production, Heliyon, 6(3), e03531(2020).

11. A. C. Opia, M. K. B. A. Hamid, S. Syahrullail, A. B. Abd Rahim, C. A. N. Johnson, Biomass as a potential source of sustainable fuel, chemical and tribological materials overview, Mater. Today: Proc., 39(2), 922-928(2021).

12. G. Mao, N. Huang, L. Chen, H. Wang, Research on biomass energy and environment from the past to the future: a bibliometric analysis, Sci. Total Environ., 635, 1081-1090(2018).

13. US EIA, International energy outlook 2011, US Energy information administration, Washington, D.C., U.S., 2011.

14. IEA, Technology roadmap: delivering sustainable bioenergy, International Energy Agency, Paris, France, 2017.

15. R. Ahorsu, F. Medina, M. Constanti, Significance and challenges of biomass as a suitable feedstock for bioenergy and biochemical production: a review, Energies, 11(12), $3366(2018)$ 
16. W. G. Hohenstein, L. L. Wright, Biomass energy production in the United States: an overview, Biomass Bioenergy, 6(3), 161-173(1994).

17. F. Cherubini, The biorefinery concept: using biomass instead of oil for producing energy and chemicals, Energy Convers. Manag., 51(7), 1412-1421(2010).

18. K. S. Rawat, Biomass to fuel: conversion Techniques, Energy resources: development, harvesting and management, O. P. Nautiyal, B. Sharma, D. Pant(Eds.), USERC, Uttrakhand, India pp. 155-194(2016).

19. IEA, Bioenergy project development and biomass supply, R. E. H. Sims, International Energy Agency, Paris, France, pp. 1-66(2007).

20. L. Rosendahl, Biomass resources, fuel preparation and utilization for improving the fuel flexibility of advanced power plants, Advanced power plant materials, design and technology, D. Roddy(Ed.), Woodhead Publishing, Sawston, U.K., pp. 312-331(2010).

21. J. Goldemberg, S. T. Coelho, Renewable energy - traditional biomass vs. modern biomass, Energy Policy, 32(6), 711-714 (2004).

22. M. K. Awasthi, S. Sarsaiya, A. Patel, A. Juneja, R. P. Singh, B. Yan, S. K. Awasthi, A. Jain, T. Liu, Y. Duan, A. Pandey, Z. Zhang, M. J. Taherzadeh, Refining biomass residues for sustainable energy and bio-products: An assessment of technology, its importance, and strategic applications in circular bio-economy, Renewable Sustainable Energy Rev., 127, 109876(2020)

23. F. H. Isikgor, C. R. Becer, Lignocellulosic biomass: a sustainable platform for the production of bio-based chemicals and polymers, Polym. Chem., 6(25), 4497-4559(2015).

24. C. Cambero, T. Sowlati, M. Pavel, Economic and life cycle environmental optimization of forest-based biorefinery supply chains for bioenergy and biofuel production, Chem. Eng. Res. Des., 107, 218-235(2016).

25. K. Lan, S. Park, Y. Yao, Key issue, challenges, and status quo of models for biofuel supply chain design, Biofuels for a more sustainable future, J. Ren, A. Scipioni, A. Manzardo, H. Liang(Eds.), Elsevier, Amsterdam, Netherlands, pp. 273-315(2020).

26. H. An, W. E. Wilhelm, S. W. Searcy, A mathematical model to design a lignocellulosic biofuel supply chain system with a case study based on a region in Central Texas, Bioresour Technol., 102(17), 7860-7870(2011).

27. M. Patel, X. Zhang, A. Kumar, Techno-economic and life cycle assessment on lignocellulosic biomass thermochemical conversion technologies: a review. Renewable Sustainable Energy Rev., 53, 1486-1499(2016).

28. W. U. K. Tareen, M. T. Dilbar, M. Farhan, M. A. Nawaz, A. W. Durrani, K. A. Memon, S. Mekhilef, M. Seyedmahmoudian, B. Horan, M. Amir, M. Aamir, Present status and potential of biomass energy in pakistan based on existing and future renewable resources, Sustainability. 12(1), 249(2020).

29. M. Shahbaz, T. Al-Ansari, M. Inayat, S. A. Sulaiman, P.
Parthasarathy, G. McKay, A critical review on the influence of process parameters in catalytic co-gasification: current performance and challenges for a future prospectus, Renewable Sustainable Energy Rev., 134, 110382(2020).

30. S. Pang, Advances in thermochemical conversion of woody biomass to energy, fuels and chemicals, Biotechnol. Adv., 37(4), 589-597(2019).

31. A. Mohsenzadeh, A. Zamani, M. J. Taherzadeh, Bioethylene production from ethanol: a review and techno-economical evaluation. ChemBioEng Rev., 4(2), 75-91(2017).

32. B. Sharma, R. G. Ingalls, C. L. Jones, A. Khanchi, Biomass supply chain design and analysis: basis, overview, modeling, challenges, and future, Renewable Sustainable Energy Rev., 24, 608-627(2013).

33. C. Zhang, H. Su, J. Baeyens, T. Tan, Reviewing the anaerobic digestion of food waste for biogas production, Renewable Sustainable Energy Rev.. 38, 383-392(2014).

34. C. Sawatdeenarunat, K. C. Surendra, D. Takara, H. Oechsner, S. K. Khanal, Anaerobic digestion of lignocellulosic biomass: challenges and opportunities, Bioresour. Technol., 178, 178-186 (2015).

35. N. Savla, S. Pandit, N. Khanna, A. S. Mathuriya, S. P. Jung, Microbially Powered Electrochemical Systems Coupled with Membrane - based Technology for Sustainable Desalination and Efficient Wastewater Treatment, J. Korean Soc. Env. Eng., 42(7), 360-380(2020).

36. S. Pandit, N. Savla, S. P. Jung, Recent advancements in scaling up microbial fuel cells, Integrated microbial fuel cells for wastewater treatment, R. Abbassi, A. K. Yadav, F. Khan, V. Garaniya(Eds.), Elsevier, Amsterdam, Netherlands, pp. 349-368(2020)

37. T. Lee, A. Okamoto, S. Jung, N. Ryuhei, J. R. Kim, K. Watanabe, K. Hashimoto, Microbial electrochemical technologies producing electricity and valuable chemicals from biodegradation of waste organic matters, Manual of environmental microbiology, M. V. Yates, C. H. Nakatsu R. V. Miller, S. D. Pillai(Eds.), ASM Press, Washington, DC, USA, pp. 5.1.4-1-5.1.4-14(2015).

38. S. P. Jung, S. Pandi, Important factors influencing microbial fuel cell performance, Microbial electrochemical technology, S. V. Mohan, S. Varjani, A. Pandey(Eds.), Elsevier, Amsterdam, Netherlands, pp. 377-406(2019).

39. M. V. Reddy, X. Sun, Bioelectrosynthesis of Various Chemicals and Evaluation of Their Microbiological Aspects, Microbial electrochemical technology, S. V. Mohan, S. Varjani, A. Pandey(Eds.), Elsevier, Amsterdam, Netherlands, pp. 757-776(2019).

40. T. Zhang, P. L. Tremblay, Possible industrial applications for microbial electrosynthesis from carbon dioxide, Microbial electrochemical technology, S. V. Mohan, S. Varjani, A. Pandey(Eds.), Elsevier, Amsterdam, Netherlands, pp. 825-842 (2019).

41. J. L. Varanasi, R. Veerubhotla, S. Pandit, D. Das, Biohydrogen production using microbial electrolysis cell: recent advances and future prospects, Microbial electrochemical technology, 
S. V. Mohan, S. Varjani, A. Pandey(Eds.), Elsevier, Amsterdam, Netherlands, pp. 843-869(2019).

42. M. J. Stolarski, M. Krzyżaniak, K. Warmiński, E. Olba-Ziety, D. Penni, A. Bordiean, Energy efficiency indices for lignocellulosic biomass production: short rotation coppices versus grasses and other herbaceous crops, Ind. Crops Prod., 135, 10-20(2019).

43. M. K. Islam, H. Wang, S. Rehman, C. Dong. H-Y. Hsu, C. S. K. Lin, S-Y. Leu, Sustainability metrics of pretreatment processes in a waste derived lignocellulosic biorefinery, Bioresour. Technol., 298, 122558(2020).

44. P. Bajpai, Energy-related environmental issues, Biomass to Energy Conversion Technologies, P. Bajpai(Ed.), Elsevier, Amsterdam, Netherlands, pp. 205-216(2020).

45. A. J. Effendi, S. Hidayat, Syafrudin, B. S. Ramadan, C. Purnawan, J-Y. Park, Performance of Microbial Reverse Electrodialysis Cells for Power Generation at Different External Resistance, Air, Soil Water Res., 13, 1-8(2020).

46. H. Kang, E. Kim, S. P. Jung. Influence of flowrates to a reverse electro - dialysis (RED) stack on performance and electrochemistry of a microbial reverse electrodialysis cell (MRC), Int. J. Hydrogen Energy, 42(45), 27685-27692(2017).

47. C. Santoro, C. Arbizzani, B. Erable, I. Ieropoulos, Microbial fuel cells: from fundamentals to applications. a review, J. Power Sources, 356, 225-244(2017).

48. S. Alatzas, K. Moustakas, D. Malamis, S. Vakalis, Biomass potential from agricultural waste for energetic utilization in Greece, Energies, 12(6), 1095(2019).

49. S. Kim, Y. F. Tsang, E. E. Kwon, K-Y. A. Lin, J. Lee, Recently developed methods to enhance stability of heterogeneous catalysts for conversion of biomass - derived feedstocks, Korean J. Chem. Eng. 36(1), 1-11(2019).

50. S. K. Hoekman, A. Broch, X. V. Liu, Environmental implications of higher ethanol production and use in the U.S.: a literature review. part I - impacts on water, soil, and air quality, Renewable Sustainable Energy Rev., 81, 3140-3158(2018).

51. X. V. Zhou, C. D. Clark, S. S. Nair, S. A. Hawkins, D. M. Lambert, Environmental and economic analysis of using SWAT to simulate the effects of switchgrass production on water quality in an impaired watershed, Agric. Water Manag., 160, 1-13(2015).

52. R. Cibin, E. Trybula, I. Chaubey, S. M. Brouder, J. J. Volenec, Watershed - scale impacts of bioenergy crops on hydrology and water quality using improved SWAT model, GCB Bioenergy, 8(4), 837-848(2016).

53. T. Guo, R. Cibin, I. Chaubey, M. Gitau, J. G. Arnold, R. Srinivasan, J. R. Kiniry, B. A. Engel, Evaluation of bioenergy crop growth and the impacts of bioenergy crops on streamflow, tile drain flow and nutrient losses in an extensively tile - drained watershed using SWAT, Sci. Total Environ., 613, 724-735(2018).
54. U.S. EPA. Biofuels and the Environment: First Triennial Report to Congress (Final Report, 2011), U.S. Environmental Protection Agency, Washington, DC, U.S. EPA/600/R-10/183F (2011).

55. M. Wu, Z. Zhang, Y. Chiu, Life - cycle water quantity and water quality implications of biofuels, Curr. Sustainable/ Renewable Energy Rep., 1(1), 3-10(2014).

56. Y. Chen, S. Ale, N. Rajan, R. Srinivasan, Modeling the effects of land use change from cotton (Gossypium hirsutum L.) to perennial bioenergy grasses on watershed hydrology and water quality under changing climate, Agric. Water Manag., 192, 198-208(2017).

57. Z. Qin, Q. Zhuang, X. Cai, Y. He, Y. Huang, D. Jiang, E. Lin Y. Liug, Y. Tang, M. Q. Wang, Biomass and biofuels in China: toward bioenergy resource potentials and their impacts on the environment, Renewable Sustainable Energy Rev., 82, 2387-2400(2018).

58. Z. Qin, J. B. Dunn, H. Kwon, S. Mueller, M. M. Wander, Influence of spatially dependent, modeled soil carbon emission factors on life - cycle greenhouse gas emissions of corn and cellulosic ethanol, GCB Bioenergy, 8(6), 1136-1149(2016).

59. Z. M. Harris, R. Spake, G. Taylor, Land use change to bioenergy: a meta - analysis of soil carbon and GHG emissions, Biomass Bioenergy, 82, 27-39(2015).

60. Y. Wu, S. Liu, C. J. Young, D. Dahal, T. S. Sohl, B. Davis, Projection of corn production and stover-harvesting impacts on soil organic carbon dynamics in the US Temperate Prairies, Sci. Rep., 5, 10830(2015).

61. W. Li, Q. Dang, R. C. Brown, D. Laird, M. M. Wright, The impacts of biomass properties on pyrolysis yields, economic and environmental performance of the pyrolysis - bioenergy - biochar platform to carbon negative energy, Bioresour. Technol., 241, 959-968(2017).

62. G. Pourhashem, Q. Z. Rasool, R. Zhang, K. B. Medlock, D. S. Cohan, C. A. Masiello, Valuing the air quality effects of biochar reductions on soil NO emissions, Environ. Sci. Technol., 51(17), 9856-9863(2017).

63. B. A. Drewniak, U. Mishra, J. Song, J. Prell, V. R. Kotamarthi, Modeling the impact of agricultural land use and management on US carbon budgets, Biogeosciences, 12(7), 2119-2129(2015).

64. J. P. McCalmont, A. Hastings, N. P. McNamara, G. M. Richter, P. Robson, I. S. Donnison, J. Clifton-Brown, Environmental costs and benefits of growing Miscanthus for bioenergy in the UK, GCB Bioenergy, 9(3), 489-507(2017).

\section{Declaration of Competing Interest}

The authors declare that they have no known competing financial interests or personal relationships that could have appeared to influence the work reported in this paper. 


\section{Authors and Contribution Statement}

\section{Ikram Mehrez}

Laboratory of Energy, Environment and Information Systems, Faculty of Sciences and Technology, Adrar University, Algeria, ph.D. Student, ORCID (10 0000-0002-9190-0260: Data Curation, Data analysis, Writing - original draft

\section{Sutha Shobana}

Department of Chemistry \& Research Centre, Mohamed Sathak Engineering College, India, Assistant Professor, ORCiD(1) 0000-0002-2108-4034: Data curation, Data analysis, Writing - original draft

\section{Georgeio Semaan}

Institute of Chemistry, Bioscience and Environmental Engineering, Faculty of Science and Technology, University of Stavanger, Norway, Student, ORCID(1) 0000-0002-4435-4711: Writing review and editing

\section{Sang-Hyoun Kim}

School of Civil and Environmental Engineering, Yonsei University, Republic of Korea, Professor ORCiD (1) 0000-0003-3835-4077: Resources, Supervision, Writing - review and editing

\section{Gopalakrishnan Kumar}

Institute of Chemistry, Bioscience and Environmental Engineering, Faculty of Science and Technology, University of Stavanger, Norway, Professor ORCID [C 0000-0002-7848-5138: Resources, Supervision, Writing - review and editing 